\title{
Cultural keystone species of fauna as a method for assessing conservation priorities in a Protected Area of the Brazilian semiarid
}

\author{
Kallyne Machado Bonifácio ${ }^{1,4}$, Eliza Maria Xavier Freire ${ }^{2}$ \& Alexandre Schiavetti ${ }^{3}$ \\ ${ }^{1}$ Universidade Federal do Rio Grande do Norte, Centro de Biociências, Curso de Doutorado em \\ Desenvolvimento e Meio Ambiente, Laboratório de Herpetologia, Natal, RN, Brazil. \\ ${ }^{2}$ Universidade Federal do Rio Grande do Norte, Departamento de Botânica e Zoologia, Laboratório de \\ Herpetologia, Natal, RN, Brazil. \\ ${ }^{3}$ Universidade Estadual de Santa Cruz, Departamento de Ciências Agrárias e Ambientais, Laboratório de \\ Etnoconservação e Áreas Protegidas, Ilhéus, BA, Brazil. \\ ${ }^{4}$ Corresponding author: Kallyne Machado Bonifácio, e-mail: kallynebonifacio@yahoo.com.br
}

BONIFÁCIO, K.M., FREIRE, E.M.X., SCHIAVETTI, A. Cultural keystone species of fauna as a method for assessing conservation priorities in a Protected Area of the Brazilian semiarid. Biota Neotropica. 16(2): e20140106. http://dx.doi.org/10.1590/1676-0611-BN-2014-0106

\begin{abstract}
The Cultural Keystone Species (CKS) method of identification has been used to define culturally important species. The objective of this study was to identify and characterize CKS vertebrates in the communities surrounding the Environmental Protection Area of Chapada do Araripe and define conservation priorities using semi-structured interviews and free listings. Interviews were conducted with 246 people; 53 species were identified and then included in categories of use: food, medicinal, handicraft and symbolic. Food preference was identified for Mazama gouazoubira, Penelope superciliaris, Dasyprocta prymnolopha and Dasypus novencimctus. As medicinal resources, Salvator merianae and M. gouazoubira represented 51.85\% of treatment recommendations. For use in handicrafts, $M$. gouazoubira, which is also the only species recorded for symbolic use, stands out. Use values (UV) varied from 0.03 to 1.34 , and M. gouazoubira had the highest UV (1.34) and a 0.74 projection. Regarding cultural importance, M. gouazoubira was the species with the highest UV and projection, and was indicated as a CKS to be prioritized in research and conservation studies.
\end{abstract}

Keywords: Ethnozoology, Mazama gouazoubira, Protected Area, Chapada do Araripe, Caatinga.

BONIFÁCIO, K.M., FREIRE, E.M.X., SCHIAVETTI, A. Espécie-Chave Cultural de fauna como método de designação de prioridades para conservação em Área Protegida do Semiárido brasileiro. Biota Neotropica. 16(2): e20140106. http://dx.doi.org/10.1590/1676-0611-BN-2014-0106

\begin{abstract}
Resumo: O método para identificação de Espécie-Chave Cultural (ECC) tem sido utilizado para definir espécies importantes culturalmente. Nesse sentido, para identificar e caracterizar ECC de vertebrados em comunidades do entorno da Área de Proteção Ambiental da Chapada do Araripe, e definir prioridades de conservação, utilizou-se formulário semiestruturado e listagem livre. Foram entrevistadas 246 pessoas; identificaram-se 53 espécies que foram incluídas nas categorias de uso: alimentar, medicinal, artesanal e simbólico. Identificou-se preferência alimentar para Mazama gouazoubira, Penelope superciliaris, Dasyprocta prymnolopha e Dasypus novencimctus. Como recurso medicinal Salvator merianae e $M$. gouazoubira representaram 51.85\% das indicações de tratamento. No uso artesanal, destaca-se $M$. gouazoubira, que também foi a única espécie registrada para o uso simbólico. Os valores de uso (VU) encontrados variaram entre 0.03 e 1.34, sendo M. gouazoubira com o VU mais alto (1.34) e 0.74 de saliência. Em relação à importância cultural, M. gouazoubira foi a espécie que apresentou maior VU, saliência e indicada como ECC, para receber prioridades em ações e estudos para conservação.

Palavras-chave: Etnozoologia, Mazama gouazoubira, Área Protegida, Chapada do Araripe, Caatinga.
\end{abstract}

\section{Introduction}

Several animal species play a significant role in cultural systems and people commonly identify with these species for cultural or economic reasons (Lohani 2010, Ferreira et al. 2013). Studies in ethnozoology conducted in different cultural contexts, such as in rural (Torres et al. 2009) and indigenous communities (Martínez 2013), have shown that a species is considered important when a utility value is assigned to it.
From a conservation point of view, the way people interact with locally important biological resources must be taken into account, since it is dynamic and susceptible to various influences (economic and socio-cultural factors, for example), a fact that is discussed in specialized literature (Alves 2009, Alves \& Dias 2010, Santos-Fita et al. 2012, Hunt 2013). Thus, understanding the issues arising from this relation (social and ecological elements) may be useful to guide conservation strategies of wildlife resources at local level. 
With this perspective, the concept of keystone species has been used with human populations in order to identify and describe the cultural importance of biological species in order to understand the particularities of cultural systems (social, economic, cultural and ecological) that affect its maintenance regarding conservation purposes (Platten \& Henfrey 2009).

The cultural keystone species method (CKS), designed by Cristancho \& Vining (2004) and adapted by Garibaldi \& Turner (2004), is a social model that proposes a categorization of species of local importance based on the intensity of established interactions of local communities with local species. CKS may be defined as "a species with a high cultural relevance to a particular social group, defining the identity of a certain place (Garibaldi \& Turner 2004) and which is critical to the stability of this group over time" (Cristancho \& Vinning 2004). It differs from ecological keystone species because it interacts with local people, although it may also play a part in ecological systems.

The first study assessing the importance of a biological species using the CKS method was conducted by Cristancho \& Vining (2004) with indigenous peoples of the Colombian Amazon. They defined that CKS would correspond to species that were present in daily life, had some kind of use and were unique in their function (non-redundant species). However, Garibaldi \& Turner (2004) evaluated that the results obtained in this study did not allow for a comparative analysis of the species, and proposed a measure of quantitative importance: the Identification Index of Cultural Influence (ICI), which is based on the sum of proportions assigned to each variable. Thus, a CKS would be the one with the highest ICI.

The CKS method is recent and has been employed in the identification of plant species that maintain the traditional way of life of communities (Cristancho \& Vining 2004, Garibaldi \& Turner 2004, Assis et al. 2010), in mediating conflicts regarding the use of natural resources (Garibaldi 2009) and in the understanding of the dynamic relation between the availability of plant species and cultural change (Barnes 2008). Despite the relevance of this method to guide biological conservation initiatives, there are no published studies using the CKS method to propose conservation priorities for animals in Brazil. The Araripe National Forest (Floresta Nacional do Araripe FLONA) presents a high diversity of vertebrates with utility potential, with 19 mammal and five reptile species (Nascimento et al. 2015); thus, the knowledge of CKS occurrences in this Protected Area may be useful to define biocultural conservation priorities of animal species used mainly for wild game purposes.

In this study, CKS refers to species that, within a cultural context and a temporal scale, are locally and/or ecologically important, but not necessarily linked to the cultural identity of a group. That's because the same species may have different historical interaction with local people who reflect on its potential use and local communities' way of life (Alves 2012). This definition takes into account that the cultural importance attached to a species by the local community may vary according to the type of social group studied, the availability and the seasonality of the species in earlier or current situations (Medeiros et al. 2013).

Assuming that the value assigned by an informant to each evaluation variable indicates more precisely the factors that affect the survival of the species assessed, one of the main contributions of the CKS approach is its effectiveness in translating information of certain cultural elements so that it is understandable to decision makers (Garibaldi \& Turner 2004). Albuquerque \& Medeiros (2013) argue that the relation between people and the use of natural resources is influenced by biological (species are selected by intrinsic factors; a higher amount of biomass, for example) and cultural factors (tradition of use) that interact with each other. Therefore, understanding this dynamic may interfere with the selection of priorities for the conservation of cultural biodiversity. The basic assumption of Biocultural Diversity is that the relation between human species and the environment is mediated by culture (Loh \& Harmon 2005).

In this context, this study's objective was to identify and characterize CKS vertebrates in communities surrounding the Environmental Protection Area (EPA) of Chapada do Araripe and propose conservation strategies through the intersection of local and scientific knowledge, with a bioecological perspective. Specifically, this study aimed to identify: 1) Which and how many animal species are known by the communities of the EPA of Chapada do Araripe; and 2) Which animal species are culturally important and subject to conservation and management actions. Answers to these questions may support management and conservation measures for wildlife, aligned with the objectives of this Protected Area (Conservation Unit - CU - Brazil).

\section{Material and methods}

\section{Study Area}

The study was conducted in in four communities in the surroundings of the EPA of Chapada do Araripe, Ceará, Brazil ( $7^{\circ} 42^{\prime} 42^{\prime \prime}$ and $7^{\circ} 50^{\prime} 28^{\prime \prime} \mathrm{S}, 39^{\circ} 17^{\prime} 04^{\prime \prime}$ and $40^{\circ} 35^{\prime} 23^{\prime \prime} \mathrm{W}$ ), (Figure 1): Caldas $\left(7^{\circ} 22^{\prime} 43^{\prime \prime} \mathrm{S}, 45^{\circ} 21^{\prime} 01^{\prime \prime} \mathrm{W}\right.$ and $\left.787 \mathrm{~m}\right)$ and Farias $\left(7^{\circ} 29^{\prime} 39^{\prime \prime} \mathrm{S}\right.$, $45^{\circ} 22^{\prime} 01^{\prime \prime} \mathrm{W}$ and $\left.693 \mathrm{~m}\right)$, from the municipality of Barbalha; Novo Horizonte $\left(7^{\circ} 29^{\prime} 39^{\prime \prime} \mathrm{S}, 45^{\circ} 22^{\prime} 01^{\prime \prime} \mathrm{W}\right.$ and $\left.837 \mathrm{~m}\right)$, from Jardim; and Banco de Areia ( $7^{\circ} 26^{\prime} 23^{\prime \prime} \mathrm{S}, 45^{\circ} 12^{\prime} 40^{\prime \prime} \mathrm{W}$ and $917 \mathrm{~m}$ ), from Missão Velha.

This Federal Protected Area has an extension of 972.590.45 hectares and covers the states of Ceará, Piauí and Pernambuco (CNUC 2011). In climatological terms, it is part of the semi-arid climate domain, with an average rainfall of $1,000 \mathrm{~mm}$ per year and average temperatures between $23^{\circ} \mathrm{C}$ and $25^{\circ} \mathrm{C}$ (Pernambuco 2007).

Local vegetation is diverse, with some areas of humid forests transitioning to "cerradão", "carrasco" and "cerrado" (RibeiroSilva et al. 2012). In general, the cerradão is a forest formation with tall, dense and bushy trees; the carrasco it is a high xerophytic dense shrub and cerrado it is a savanna formation with low and sparse trees (Roberts \& Araújo 2013 Araújo et al. 1999).

The EPA of Chapada do Araripe is considered an area of extreme priority for the conservation of biodiversity in Caatinga areas (including forest formations and non-forests), that are still little known from a biological point of view (MMA 2007). The Caatinga domain, an exclusively Brazilian ecosystem of the semiarid region, comprises an ample variety of vegetation formations characterized according to factors such as altitude, floristic composition and soil composition (Albuquerque et al. 2012). This domain has suffered strong extractivist pressure especially from the conversion of natural areas into pastures or plantations (Oliveira et al. 2007). Originally with 827,934 sq. $\mathrm{km}$, it is the least protected Brazilian biome, with $7.6 \%$, the equivalent of 62,697 sq. km, of its original area in Conservation Units (CUs), of which $1.2 \%$ is of Integral Protection and $6.4 \%$ of Sustainable Use (CNUC 2015).

According to the National Register of Protected Areas (CNUC 2011), this EPA does not yet have management tools that allow territory usage planning. 


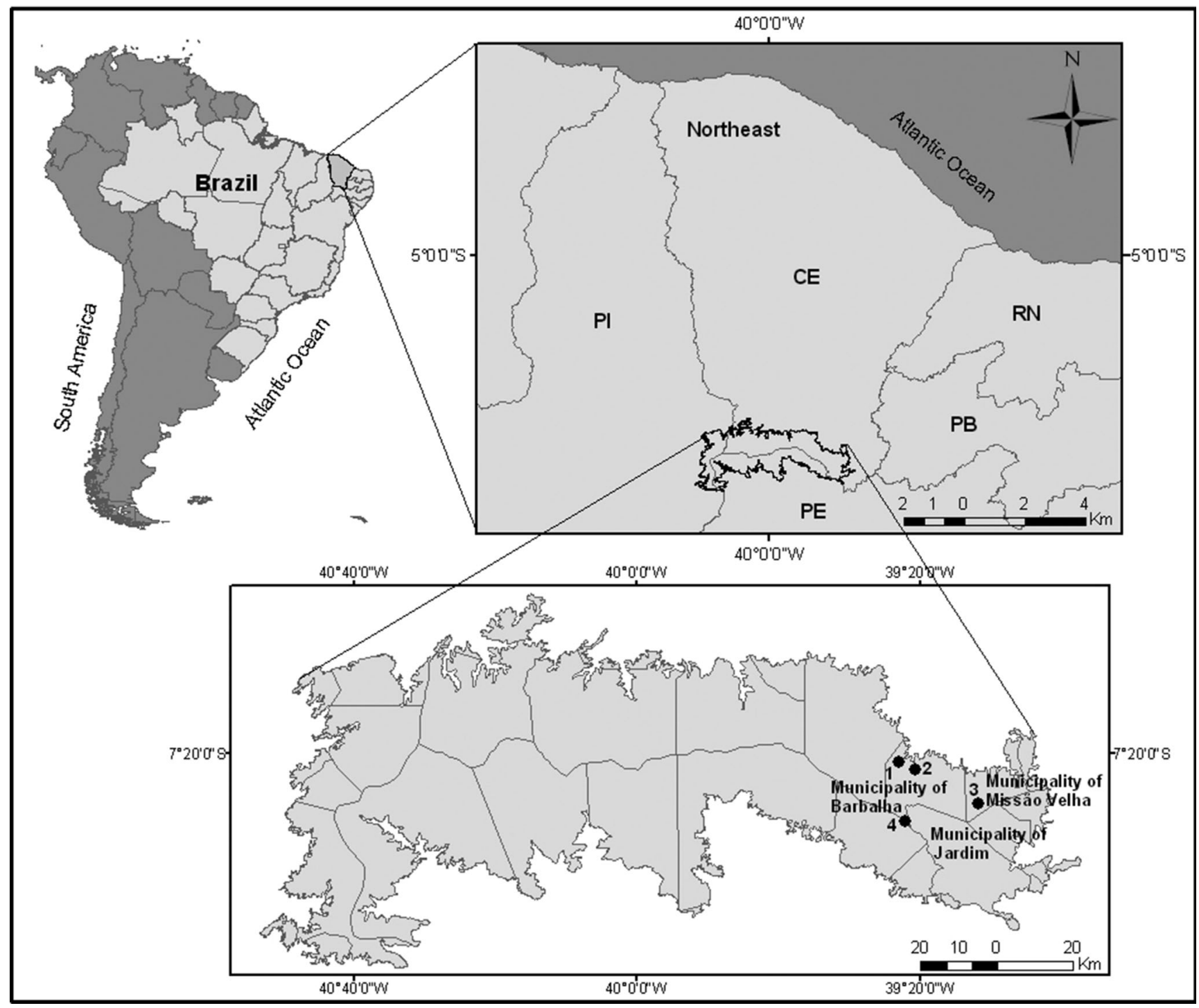

Figure 1. EPA Chapada do Araripe location and the four studied communities in their surroundings, in the state of Ceará, Brazil. 1: Caldas Community; 2: Farias community; 3: Banco de Areia Community; 4: Novo Horizonte Community.

\section{Data collection}

Data collection occurred in March 2012 and January to February 2013. Information was collected with semi-structured interviews and free listings, with the consent of the interviewees with the free and informed consent (FIC) form approved by the Research Ethics Committee (REC) of the Federal University of Rio Grande do Norte (UFRN), REC/UFRN no. 227/12.

The sample universe included men and women over 18 years of age with a minimum residence of 10 years in the locality; only one member of each family was interviewed in accordance with previously established criteria. The Snowball technique (Bernard 1996) was used to select respondents, which consists of selecting research participants based on recommendation of others.

A total of 246 people were interviewed, with ages varying between 20 and 90 , with an average of $50( \pm 17.91)$ years. The interviewees practice subsistence farming, mainly cultivating beans, manioc and corn. Among the most important activities for the local economy are the extraction of pequi fruit (Caryocar coriaceum Wittm.) and field beans (Dimorphandra gardneriana Tul.) (Sousa Júnior et al. 2013). General data of the four communities studied is summarized in Table 1.

There was a difference between the number of men $(n=173)$ and women $(n=73)$ due to the fact that women refused to participate in the study when their husbands were present during the visits, explaining that the knowledge about animals belonged to the men. According to Torres et al. (2014), the gender variable reflects differences in the production of knowledge and, therefore, in the amount of known animals, and the type of information provided may differ between men and women. Unpublished research conducted by the same authors of the present study in the same communities found significant differences in the number of species cited between men and women, verifying that the men know more animals than the women $(\mathrm{men}=10.35 \pm 4.88$ animals; women $=10.24 \pm 4.67 ; \mathrm{U}=6811 ; \mathrm{p}=0,697)$. This may be explained by the fact that the men participate in activities that offer a more direct interaction with the environment, such as hunting and farming (Pfeiffer \& Butz 2005).

The semi-structured interview contained four questions regarding interviewees' profile data and seven related to 
Table 1. General data of the four studied communities in the surroundings of the EPA Chapada do Araripe, Ceará (NE Brazil).

\begin{tabular}{|c|c|c|c|c|}
\hline Characteristics & Caldas & Farias & Novo Horizonte & Banco de Areia \\
\hline Municipality & Barbalha & Barbalha & Jardim & Missão Velha \\
\hline Total number of families* & 142 & 116 & 272 & 116 \\
\hline Total number of interviewees & 57 & 56 & 82 & 51 \\
\hline \multicolumn{5}{|l|}{ Number of interviewees } \\
\hline \multicolumn{5}{|l|}{ Gender } \\
\hline Men & 40 & 41 & 55 & 37 \\
\hline Women & 17 & 15 & 27 & 14 \\
\hline Age (mean in years) & 54.1 & 64.62 & 51.91 & 45.56 \\
\hline \multicolumn{5}{|l|}{ Occupation (\%) } \\
\hline Agriculture & 14.13 & 32.14 & 31.70 & 52.94 \\
\hline Retired & 38.02 & 46.42 & 21.95 & 13.72 \\
\hline Time of residency (mean) & 46.12 & 60.62 & 48.17 & 39.78 \\
\hline
\end{tabular}

*Population estimated by the local health center in 2012.

knowledge about the local fauna (vernacular names and uses). To collect information on the known animal species, a free listing was consolidated with the help of the following guiding question: Which animals of leather, hull and feather exist in the mountains? This classification was defined based on the specific vocabulary of the local population and was used by the researcher to facilitate understanding by the interviewees. The percentage of mentions was calculated relative to the total number of respondents in order to identify the species of major and minor importance locally.

We confirmed the species listed in the interviews using techniques recommended by Alves \& Souto (2010), such as displaying an album to each respondent containing photos of the animals that occur in the study area, with the list of species documented in the National Forest of Araripe Management Plan (IBAMA 2004) as a reference, and with animal parts donated by respondents and/or collected by the researcher.

The taxonomic classification and nomenclature of reptile, bird and mammal species mentioned in this study followed, respectively, the rules of the Brazilian Society of Herpetology (Bérnils et al. 2010), of the Brazilian Committee of Ornithological Registration (CBRO 2011) and of the annotated List of Mammals of Brazil (Paglia 2012).

\section{Data analysis}

To evaluate sampling efforts in each community, the cumulative curve of species (Cowell \& Coddington 1994) from 1000 randomizations was used, plotting the number of interviews (x-axis) and the number of ethnospecies (y-axis) on the matrix; the richness of ethnospecies was estimated by the Chao 2 diversity estimator with the help of the EstimateS 8.2.0 software (Cowell 2009). The nonparametric estimator Chao 2 is based on the richness of species found in only one sample as well as in exactly two samples, and requires only the use of a qualitative data matrix (presence or absence) (Magurran 2011). Due to these features, Chao 2 is indicated for ethnozoological studies (Alves et al. 2012).

The use value (UV) of animal species mentioned is calculated with the formula (modified from Rossato et al., 1999) $U V=\sum U / n$, where $U V=$ index of the species' use value; $U=$ number of mentions per ethnoespecies; $n=$ number of respondents. This formula was used to identify the most important species. The mentions of use were analyzed by calculating the Fidelity Level (FL, Friedman et al. 1986), obtained by: FL = Ip / Iu x 100\%, where FL = fidelity level; Ip $=$ number of informants who suggest use of a particular animal as the main purpose, and $\mathrm{Iu}=$ total number of respondents who mentioned the animal for any purpose. According to this index, the greater the consensus among respondents regarding the use mentioned for a species, the higher the FL, where $100 \%$ is the maximum value that the species can reach. To verify the level of importance of each species for the communities studied, the Smith's Salience Index (Smith S) was calculated using the Anthropac 4.0 software (Borgatti 1996). The Salience Index takes into account the frequency with which a species is mentioned and the amount of times it was mentioned in a certain order (Smith 1993). The species with the highest salience value represents the species most mentioned. The possible relationship between UV and Smith's Salience Index was tested by Pearson correlation (r), using SPSS Software.

Regarding the assessment of CKS, the analysis resorted to an important timeframe connected to the Protected Area in order to enable all respondents to think in the same timeframe when mentioning the three most important animal species to them: Of the animals that you mentioned earlier (leather, hull and feather animals), which were the most used (good for use) when there was open forest around the mountain? Name at least three most important animals in your order of preference (Dos bichos que você citou [de couro, de casco e de pena] quais foram os mais usados [bom de serventia] quando a mata da serra era aberta? Diga o nome de pelo menos três mais importantes em uma ordem do mais preferido). The period in question refers to the years between 1947 and 1965, the period in which hunting, as a subsistence resource, was not prohibited. Moreover, people had free access to Serra do Araripe to cultivate cassava (Manihot sculenta, Cranz) and raise cattle, which provided a more direct contact with wildlife resources, with the consequent recognition of animals of local importance. After 1965, the forest was "closed", restricting the use of natural resources (plants and animals) by local people.

Although $15.85 \%$ of the interviewed have not experienced the key event, these people took as reference the recent environment and cultural information acquired to report potentially useful animal species. In addition, the residence 
time more than 10 years in the location is considered sufficient for a minimum knowledge of the local fauna and their uses (Gehara 2009, Lopes et al. 2009). According to Donnell et al. (2010), when the use of a resource is associated with a landmark event for the local community, this relation can help the interviewee to more easily remember the most important cultural significance resource and its type of use.

After mapping of the three species, a CKS indicator called ICI was developed (Garibaldi \& Turner 2004), which calculates the sum of the weighted average of values ??from 0 to 3 ( 0 - no, 1 - little, 2 - reasonably; 3 - high), assigned by all respondents to each variable, adapted from Garibaldi \& Turner (2004). In this study, CKS assessment variables considered appropriate to calculate ICI were: use, popularity, availability and history. The end result led to an animal species system, in which the highest ICI value elects the animal species that fits the CKS category. Species with an ICI $>10$ were established as a top priority for conservation; species with an ICI between $9-10$, as a high priority; species with an ICI between $5-8$, as relevant for conservation; and species with an ICI $\leq 5$ were considered low priority.

\section{Results and discussion}

\section{Ethnospecies richness}

In free listings, 53 animal ethnospecies were mentioned, distributed in three taxonomic categories: Birds, Reptiles and Mammals, comprising 50 genera and 31 families (Table 2). Among the species mentioned, the groups that had a greater representation regarding richness were birds, with 34 species $(64.15 \%)$ and mammals with 17 species (32.07\%). As for families, Columbidae (14 spp.), Tynamidae (12 spp.) and Emberezidae (3 spp.) showed a higher number of species mentioned for the bird group. Among mammals, Felidae (4 spp.) represented the family with the highest number of species mentioned, followed by Dasypodidae and Canidae (3 spp. each). The reported richness of species corresponds to those with some kind of known use in the study area. The number of species recorded in this study proved to be compatible with what is mentioned in other ethnozoological studies in semi-arid regions of Northeastern Brazil, which ranged from 38 (Barbosa et al. 2011) to 81 species (Alves et al. 2012). The predominance of a greater richness of birds is probably due to the abundance and/or variety of this group in the studied area, a fact also noted by Torres et al. (2009) for the Caatinga. According to the Management Plan (IBAMA 2004), the National Forest of Araripe has 193 bird species and 37 mammal species. On the other hand, in another semi-arid area, "Tupinambá of Olivença", inhabited by indigenous communities (Bahia), a different result was found: of the 42 species mentioned, 30 belonged to mammals and 7 to birds (Pereira \& Schiavetti 2010). According to these authors, the greater diversity of mammals mentioned may be related to the availability and/or preference for these animals, but also to energy benefits, as the study reveals a richness of hunted species. A greater taxonomic richness for mammals $(\mathrm{n}=16)$ was also reported by Altrichter (2006) in the arid area of Argentine Chaco. In both studies, hunting is a deeply rooted and widespread custom in the population. In the case of arid regions, due to poverty coupled with social and economic marginalization, much of the diet of rural communities is still sustained by wild meat consumption, and mammals provide $92 \%$ of the protein demand (Altrichter 2006).

According to the cumulative curve of ethnospecies mentions, the number of interviews was satisfactory to conclude the richness of locally known animal species, since there was a stabilization of the number of mentioned ethnospecies $(n=53)$ around the $244^{\text {th }}$ interview. The richness indicated by the Chao 2 estimator was 52 species, with $95 \%$ confidence interval, ranging from 51.99 to 52.09 (Figure 2).

\section{Relative importance of ethnospecies: uses and cultural salience}

Of the 53 ethnospecies animals listed, 15 belonging to 11 families were recorded with some value to the communities studied: mammals (9 spp.; 60\%) and birds (5spp.; 33.3\%) represent the zoological groups with the highest number of mentioned species (Table 3). Together, these animals fall into four categories of use: food (15 spp./1359 mentions $/ 89.05 \%$ of the total of mentions), medicinal (8 spp./102 mentions/6.68\%), handicraft (4 spp./52 mentions/3.40\%) and symbolic ( $2 \mathrm{spp} . / 15$ mentions $/ 0.98 \%$ ). The consensus among the interviewees' answers on known uses is detailed in Table 3 . In different studies conducted in the Caatinga (Costa-Neto 2000, Oliveira et al. 2010b, Melo et al. 2014) on the use of wildlife, birds and mammals are among the most mentioned taxa in number of species, which demonstrates the cultural importance given to these animals. The highest number of species in the food and medicinal categories was a pattern observed by Alves (2009), while reviewing research on zootherapeutic practices in semi-arid environments, mainly explained by the role of wildlife as a protein source in different parts of the world.

\section{Categories of Use}

3.1. Food resource. In studied communities, obtaining meat for food was recorded as the primary use of wildlife, indicating a preference for the following animals (Table 4): common deer, Mazama gouazoubira G. Fischer, $1814 \quad(\mathrm{n}=237$ mentions/ $17.43 \%, \mathrm{FL}=77.21 \%$ ); guan, Penelope superciliaris Temminck, $1815(\mathrm{n}=211 / 15.52 \% ; \mathrm{FL}=98.11 \%) ;$ agouti, Dasyprocta prymnolopha Wagler, $1831(\mathrm{n}=205 / 15.8 \%$; FL $=98.5 \%)$; and common armadillo, Dasypus novemcinctus (Linnaeus, 1758) $(\mathrm{n}=195 / 14.34 \% ; \mathrm{FL}=94.41 \%)$. The significant number of mentions of the common deer ( $M$. gouazoubira) may be related to its size (amount of biomass obtained in hunting activity), to the appreciable flavor and tenderness of the meat, or to it being considered "healthy". Santos-Fita et al. (2012), in a similar study with rural communities in Mexico, also found Mazama sp. among the animals with most mentions for consumption due to palatability and the nutritional value of its meat. On the other hand, Altrichter (2006), in Argentine Chaco, registered unanimous consumption of "tatu-bola", Tolypeutes matacos (Desmarest, 1804), justified by the quality of the meat, and a secondary preference for M. gouazoubira. According to the same author, this preference may be due to the disappearance of highproductivity mammals $(>10 \mathrm{~kg})$ in habitats near communities.

The preference for wild animals whose protein supply is considerable $(>10 \mathrm{~kg}$ ) constitutes a tendency in other regions of Brazil (Pereira \& Schiavetti 2010, Barbosa et al. 2011, Alves et al. 2012) and of Latin America (Quijano-Hernández \& Calme 2002, Hurtado-Gonzales \& Bodmer 2004, Gil \& Giáscon 2012). 
Table 2. Animal species mentioned by EPA Chapada do Araripe communities, Ceará (NE Brazil).

\begin{tabular}{|c|c|c|c|}
\hline \multirow[t]{2}{*}{ Family/ Species } & \multirow[t]{2}{*}{ Local Name $/ \mathrm{N}^{\circ}$ of citations } & \multicolumn{2}{|c|}{ Conservation Status } \\
\hline & & MMA & IUCN \\
\hline \multicolumn{4}{|l|}{ BIRDS } \\
\hline \multicolumn{4}{|l|}{ Tinamidae } \\
\hline Crypturellus noctivagus zabele (Spix, 1825) & "zabelê" (yellow-legged tinamou)/21 & VU & NT \\
\hline Crypturellus parvirostris (Wagler,1827) & "nambu" (Small-billed tinamou)/73 & - & $\mathrm{LC}$ \\
\hline Nothura maculosa (Temminck, 1815) & "corduniz" (spotted nothura)/65 & - & $\mathrm{LC}$ \\
\hline \multicolumn{4}{|l|}{ Accipritidae } \\
\hline Rupornis magnirotris (Gmelin, 1788) & "gavião" (hawk)/23 & - & $\mathrm{LC}$ \\
\hline \multicolumn{4}{|l|}{ Falconidae } \\
\hline Caracara plancus (Miller, 1777) & "carcará" (southern carcara)/18 & - & - \\
\hline \multicolumn{4}{|l|}{ Cracidae } \\
\hline Penelope superciliaris (Temminck, 1815) & “jacu” (guan)/ 211 & - & $\mathrm{LC}$ \\
\hline \multicolumn{4}{|l|}{ Carimidae } \\
\hline Cariama cristata (Linnaeus, 1766) & Sariema/ 102 & - & $\mathrm{LC}$ \\
\hline \multicolumn{4}{|l|}{ Columbidae } \\
\hline Columbina minuta (Linnaeus, 1766) & "rolinha comum"(common turtle dove)/48 & - & $\mathrm{LC}$ \\
\hline Columbina talpacoti (Temminck, 1811) & "rolinha caldo de feijão" (ruddy ground dove)/17 & - & $\mathrm{LC}$ \\
\hline Columbina squamatta (Lesson, 1831) & "rolinha cascaval" (scaled dove)/17 & - & - \\
\hline Leptotila verreauxi Bonaparte, 1855 & "juriti" (white-tipped dove)/ 70 & - & $\mathrm{LC}$ \\
\hline Zenaida auriculata (Des Murs, 1847) & "ribaçã" (eared dove)/ 10 & - & $\mathrm{LC}$ \\
\hline \multicolumn{4}{|l|}{ Psittacidae } \\
\hline Eupsittula cactorum (Kuhl, 1820) & "guinguirro" (cactus parakeet)/24 & - & $\mathrm{LC}$ \\
\hline Forpus xanthopterygius (Spix, 1824) & "pacu" (Blue-winged parrotlet)/ 6 & - & - \\
\hline \multicolumn{4}{|l|}{ Cuculidae } \\
\hline Crotophaga ani Linnaeus, 1758 & "anu preto" (smooth-billed ani)/2 & - & - \\
\hline Guira guira (Gmelin, 1788) & "anu branco" (guira cuckoo)/1 & - & $\mathrm{LC}$ \\
\hline Piaya cayana (Linnaeus, 1766) & "alma de gato" (squirrel cuckoo)/7 & - & $\mathrm{LC}$ \\
\hline \multicolumn{4}{|l|}{ Strigidae } \\
\hline Glaucidium brasilianum (Gmelin, 1788) & "caburé" ferruginous pygmy owl)/12 & - & $\mathrm{LC}$ \\
\hline Megascops choliba choliba (Vieillot, 1817) & "coruja" (owl)/12 & - & $\mathrm{LC}$ \\
\hline \multicolumn{4}{|l|}{ Nyctibiida } \\
\hline Nyctibus griséus (Gmelin, 1789) & "mãe da lua"/12 & - & - \\
\hline \multicolumn{4}{|l|}{ Trochilidae } \\
\hline Chlorostilbon luciduss (Shaw, 1812) & "bizunga"/12 & - & - \\
\hline Eupetomena macroura (Gmelin, 1788) & "tesourão" (swallow-tailed hummingbird)/2 & - & $\mathrm{LC}$ \\
\hline \multicolumn{4}{|l|}{ Bucconidae } \\
\hline Nystalus maculatus (Gmelin, 1788) & "fura-barreiro" (puffbird)/2 & - & $\mathrm{LC}$ \\
\hline \multicolumn{4}{|l|}{ Picidae } \\
\hline Veniliornis passerinus (Linnaeus, 1766) & "pica-pau-pequeno" (woodpecker)/14 & - & - \\
\hline \multicolumn{4}{|l|}{ Tyrannidae } \\
\hline Fluvicola negenta (Linnaeus, 1766) & "lavadeira"/5 & - & - \\
\hline Pitangus sulphuratus (Linneus, 1766) & "bem-te-vi" (great kiskadee) & - & $\mathrm{LC}$ \\
\hline \multicolumn{4}{|l|}{ Pripidae } \\
\hline $\begin{array}{l}\text { Antilophia bokermanni Coelho \& Silva, } 1998 \\
\text { Corvidae }\end{array}$ & "soldadinho-do-araripe" (Araripe manakin)/20 & $\mathrm{CR}$ & $\mathrm{CR}$ \\
\hline Cyanocorax cyanopogon (Wied, 1821) & "cancão" (white-naped jay)/33 & - & $\mathrm{LC}$ \\
\hline Troglodytidae & & & \\
\hline Pheugopedius genibarbis (Swainson, 1838) & "chorró" (moustached wren)/6 & - & $\mathrm{LC}$ \\
\hline Turdidae & & & \\
\hline Turdus leucomelas Vieillot, 1818 & "sabiá comum" (pale-breasted thrush)/34 & - & $\mathrm{LC}$ \\
\hline Turdus rufiventris (Vieillot, 1818) & "sabiá peito amarelo" (rufous-bellied thrush)/13 & - & $\mathrm{LC}$ \\
\hline Thraupidae & & & \\
\hline Sicalis flaveola (Linnaeus, 1776) & "canário da terra" (saffron finch) $/ 8$ & - & $\mathrm{LC}$ \\
\hline Parulidae & & & \\
\hline Setophaga fusca (Statius Muller, 1776) & "papo de fogo" (lackburnian warbler)/3 & - & $\mathrm{LC}$ \\
\hline Myiothlypis flaveola Baird, 1865 & "canário comum" (common canary)/9 & - & $\mathrm{LC}$ \\
\hline
\end{tabular}


Cultural keystone species of fauna

Table 2. Continued.

\begin{tabular}{|c|c|c|c|}
\hline \multirow[t]{2}{*}{ Family/ Species } & \multirow[t]{2}{*}{ Local Name $/ \mathrm{N}^{\circ}$ of citations } & \multicolumn{2}{|c|}{ Conservation Status } \\
\hline & & MMA & IUCN \\
\hline \multicolumn{4}{|l|}{ MAMMALIA } \\
\hline \multicolumn{4}{|l|}{ Didelphidae } \\
\hline Didelphis albiventris(Lund, 1840) & "cassaco" (white-eared Opossum)/27 & - & $\mathrm{LC}$ \\
\hline \multicolumn{4}{|l|}{ Dasypodidae } \\
\hline Cabassous unicinctus (Linnaeus, 1758) & "china" (southern naked-tailed armadillo)/69 & - & $\mathrm{LC}$ \\
\hline Dasypus novencimctus (Linnaeus, 1758) & "tatu comum" (common armadillo)/195 & - & $\mathrm{LC}$ \\
\hline Euphractus sexcinctus (Linnaeus, 1758) & "peba" (six-banded armadillo)/194 & - & $\mathrm{LC}$ \\
\hline \multicolumn{4}{|l|}{ Canidae } \\
\hline Cerdocyon thous (Linnaeus, 1766) & "raposa" (fox)/82 & - & $\mathrm{LC}$ \\
\hline Nasua Nasua (Linnaeus, 1766) & "coati"/20 & - & $\mathrm{LC}$ \\
\hline Procyon cancrivorus (G. Cuvier, 1798) & "guaxinim" (raccoon)/19 & - & $\mathrm{LC}$ \\
\hline \multicolumn{4}{|l|}{ Mustelidae } \\
\hline Conepatus semistriatus (Boddaert, 1785) & "gambá" (possum)/51 & - & $\mathrm{LC}$ \\
\hline Galictis vitatta (Schreber, 1776) & "furão" (ferret)/15 & - & $\mathrm{LC}$ \\
\hline \multicolumn{4}{|l|}{ Felidae } \\
\hline Leopardus tigrinus Shreber, 1775 & "gato do mato; lagartcheiro" (oncilla; tiger cat)/45 & EN & VU \\
\hline Leopardus wiedii (Schinz, 1821) & "gato maracajá" (margay cat)/7 & VU & - \\
\hline Panthera onca Linnaeus, 1758 & "onça pintada" (spotted jaguar)/45 & VU & NT \\
\hline Puma concolor (Linnaeus, 1771) & "onça vermelha" (red jaguar)/130 & VU & $\mathrm{LC}$ \\
\hline Mazama gouazoubira (G. Fischer, 1814) & "veado comum" (common deer)/237 & - & $\mathrm{LC}$ \\
\hline \multicolumn{4}{|l|}{ Caviida } \\
\hline Galea spixii (Wagler, 1831) & "preá" (guinea pig)/40 & - & $\mathrm{LC}$ \\
\hline \multicolumn{4}{|l|}{ Dasyproctidae } \\
\hline Dasyprocta prymnolopha (Wagler, 1831) & "cutia" (agouti)/205 & - & $\mathrm{LC}$ \\
\hline \multicolumn{4}{|l|}{ Myrmecophagidae } \\
\hline Tamandua tetradactyla (Linnaeus, 1758) & "tamanduá" (anteater)/113 & - & $\mathrm{LC}$ \\
\hline \multicolumn{4}{|l|}{ REPTILIA } \\
\hline \multicolumn{4}{|l|}{ Iguanidae } \\
\hline Iguana iguana (Linnaeus, 1758) & "camaleão" (chameleon)/38 & - & - \\
\hline \multicolumn{4}{|l|}{ Teiidae } \\
\hline Salvator merianae (Duméril \&Bibron,1839) & "teiú" (black and white tegu")/88 & - & $\mathrm{LC}$ \\
\hline
\end{tabular}

Legend: Categories of the Red List of IUCN (2014.1): DD - Data deficient, LC - Least Concern, NT - Near Threatened, VU - Vulnerable, CR Critically endangered. Categories of Brazilian Red List (MMA, 2008): CE- Critically endangered, E - Endangered, VU - Vulnerable.

The low consensus (low FL) regarding the common deer, $M$. gouazoubira, compared to other species used as food, is due to the fact that respondents assigned different uses (more than two) for this species besides its main use. This study recorded multiple uses for common deer, including handicraft, symbolic and medicinal uses. Other studies have verified this versatility of the common deer in local communities (Altrichter 2006, Gehara et al. 2009).

Small species also substantially contribute to the amount of meat used for food. The guan ( $P$. superciliaris) was appointed as a preference in the communities of Caldas (52 mentions/17.16\%) and Novo Horizonte (74 mentions/16.12\%); agouti, D. prymnolopha (40 mentions $/ 15.62 \%$ ) in Banco de Areia; and common armadillo, D. novemcinctus (52 mentions/15.24\%) in Farias, suggesting that these species must be hunted with some frequency. In addition, related preferences reside in the taste and flavor of the meat and possibly in the availability of these animals, as well as their being easy to capture. These results are in agreement with studies that show that the choice of local species hunted for food is influenced by availability, richness and size (Alves et al. 2012). On the other hand, they differ from
Althrichter (2000), who studied the indigenous people of Costa Rica, where it was found that consumption of a species reflects the appreciation of the meat and not its availability.

In this study we found that women in the studied communities avoid a group of animals as a food resource: peba, Euphractus sexcinctus (Linnaeus, 1758); china, Cabassous unicinctus (Linnaeus, 1758); agouti (D. prymnolopha); cavy, Galea spixii (Wagler, 1831); anteater, Tamandua tetradactyla (Linnaeus, 1758); juriti, Leptotila verreauxi Bonaparte, 1855; and common armadillo (D. novemcinctus). This is due to temporary taboos, especially due to shrewishness ("carrego"), which suggests that respondents believe that avoiding these animals preserves their health. Temporary taboos are defined as food bans during certain life periods, such as during menstruation, pregnancy and postpartum, since they are considered offensive (Colding \& Folke 2001). Jorgenson (1995) found a rejection, regardless of gender, of the consumption of $D$. novemcinctus among indigenous people from Mexico, motivated by the very fat and tasteless meat. From a conservation point of view, the restriction on the use of animals may promote availability of these species over time. 


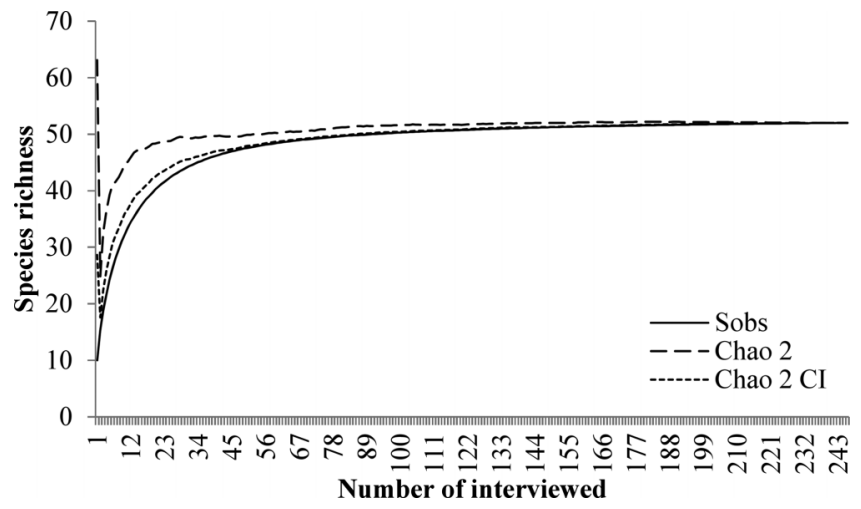

Figure 2. Cumulative curve of ethnospecies of the EPA Chapada do Araripe's fauna mentioned by 246 interviewees. Sobs: 53; Expected richness: Chao $2=52$, stabilization curve, $\mathrm{n}=244$ interviews. CI: $95 \%$ confidence interval.

Respondents unanimously stated that the consumption of "peba", E. sexcinctus, increased for women in times of menses, at the risk of causing diseases such as leg swelling, blood thinning followed by an increased menstrual flow and unpleasant odor. A respondent from the Banco de Areia community (L.A.B.,
58 years old) also pointed out that this restriction is lifted at the age of 60, at the postmenopausal stage. This species was cited by Souza \& Alves (2014), in the Atlantic Forest area of Paraiba, as restrictive for human consumption due to the omnivorous habit of the species. "Peba", E. sexcinctus, is considered a generalist animal, whose diet includes mortal remains (Alves et al. 2012), which suggests that the shrewishness from peba meat may be due not only to the fat, but also to the lack of selection of the animal's diet.

3.2. Medicinal resource. The belief in the healing properties of fauna was the second largest use reported by respondents of the communities studied (Table 4). Eight ethnospecies (2 birds, 5 mammals and 1 reptile) which can be used to treat 18 kinds of diseases (Table 5) were mentioned. The parts mentioned by respondents were horn, leather, tail, shin, liver, fat (lard), urine, feces and feather, with lard being the most used as zootherapeutic (6 recommendations for use; $37.5 \%$ of recommendations), used to treat 10 kinds of diseases, especially respiratory (asthma, otitis, sore throat) and muscle diseases (rheumatism and swelling in the legs). This finding is consistent with the work of Ferreira et al. (2009) and Vasconcelos-Neto et al. (2012), which refer to lard as the raw material most used in the treatment and cure of various diseases; this was also recorded by Martínez (2013) for the communities of Toba, Argentina.

Table 3. Fidelity Level of animal species with use value mentioned by surrounding communities of EPA Chapada do Araripe, Ceará (NE Brazil).

\begin{tabular}{|c|c|c|c|}
\hline Family/Species & Local name & Main use & FL $(\%)$ \\
\hline \multicolumn{4}{|l|}{ BIRDS } \\
\hline \multicolumn{4}{|l|}{ Tinamidae } \\
\hline Crypturellus noctivagus zabele (Spix, 1825) & zabelê (yellow-legged tinamou) & medicinal & 100 \\
\hline Crypturellus parvirostris (Wagler,1827) & nambu (small-billed tinamou) & food & 100 \\
\hline Nothura maculosa (Temminck, 1815) & corduniz (spotted nothura) & food & 100 \\
\hline \multicolumn{4}{|l|}{ Cracidae } \\
\hline Penelope superciliaris (Temminck, 1815) & jacu (guan) & food & 98.11 \\
\hline \multicolumn{4}{|l|}{ Columbidae } \\
\hline Leptotila verreauxi Bonaparte, 1855 & juriti (white-tipped dove) & food & 100 \\
\hline \multicolumn{4}{|l|}{ MAMMALIA } \\
\hline \multicolumn{4}{|l|}{ Dasypodidae } \\
\hline Cabassous unicinctus (Linnaeus, 1758) & china (southern naked-tailed armadillo) & food & 100 \\
\hline Dasypus novencimctus (Linnaeus, 1758) & tatu comum (common armadillo) & food & 94.41 \\
\hline Euphractus sexcinctus (Linnaeus, 1758) & peba (six-banded armadillo) & food & 97.48 \\
\hline \multicolumn{4}{|l|}{ Canidae } \\
\hline Cerdocyon thous (Linnaeus, 1766) & raposa (fox) & medicinal & 72.72 \\
\hline \multicolumn{4}{|l|}{ Mustelidae } \\
\hline Conepatus semistriatus (Boddaert, 1785) & gambá (skunk) & medicinal & 100 \\
\hline \multicolumn{4}{|l|}{ Cervidae } \\
\hline $\begin{array}{l}\text { Mazama gouazoubira (G. Fischer, 1814) } \\
\text { Caviida }\end{array}$ & veado comum (common deer) & food & 77.21 \\
\hline Galea spixii (Wagler, 1831) & preá (guinea pig) & food & 100 \\
\hline \multicolumn{4}{|l|}{ Dasyproctidae } \\
\hline \multicolumn{4}{|l|}{ Mymercophagidae } \\
\hline \multicolumn{4}{|l|}{ REPTILIA } \\
\hline \multicolumn{4}{|l|}{ Teiidae } \\
\hline Salvator merianae (Duméril \& Bibron,1839) & teiú (black and white tegu) & medicinal & 100 \\
\hline
\end{tabular}


Table 4. Animal species and their respective categories of use, utilized parts, cited by the inhabitants of the communities surrounding the EPA Chapada do Araripe (NE Brazil).

\begin{tabular}{|c|c|c|c|c|}
\hline Family/Species & Local name & $\begin{array}{l}\mathbf{N}^{\circ} \text { of } \\
\text { citations }\end{array}$ & Category of use & Part used \\
\hline
\end{tabular}

\section{BIRDS}

Tinamidae

Crypturellus noctivagus

zabele (Spix, 1825)

Crypturellus parvirostris

(Wagler,1827)

Nothura maculosa

(Temminck, 1815)

\section{Cracidae}

Penelope superciliaris

(Temminck, 1815)

\section{Columbidae}

Leptotila verreauxi

Bonaparte, 1855

Zenaida auriculata

(Des Murs, 1847)

\section{MAMMALIA \\ Dasypodidae}

Cabassous unicinctus

(Linnaeus, 1758)

Dasypus novencimctus

(Linnaeus, 1758)

Euphractus sexcinctus

(Linnaeus, 1758)

Canidae

Cerdocyon thous

(Linnaeus, 1766)

Mustelidae

Conepatus semistriatus

(Boddaert, 1785)

Family/Species

\section{Cervidae}

Mazama gouazoubira

(G. Fischer, 1814)

Dasyproctidae

Dasyprocta prymnolopha

(Wagler, 1831)

Myrmecophagidae

Tamandua tetradactyla

(Linnaeus, 1758)

\section{REPTILIA}

Teiidae

Salvator merianae

(Duméril \&Bibron,1839)

$\begin{array}{lclc}\begin{array}{l}\text { zabelê (yellow-legged } \\ \text { tinamou) }\end{array} & 21 & \text { medicinal } & \text { feather } \\ \begin{array}{l}\text { nambu (Small-billed } \\ \text { tinamou) }\end{array} & 73 & \text { food } & \text { meat } \\ \text { corduniz (spotted nothura) } & 65 & \text { food } & \text { meat }\end{array}$

jacu (guan)

211

food, medicinal

meat, fat

meat

ribaçã (Eared dove)

10 food

meat

china (Southern naked-

69

food

meat

tailed armadillo)

tatu comum (Common

195 food, medicinal

meat, tail

armadillo)

peba (Six-banded

194 food

meat

armadillo)

raposa (Fox)

82

medicinal, handicraft

fat, leather

gambá (Skunk)

51 medicinal

fat

\section{Local name}

\section{$\mathbf{N}^{\circ}$ of}

Category of use

citations

veado comum (common

food, medicinal, handicraft symbolic

meat, leather, fat, liver, feces, horn, paw

cutia (Agouti)

food, handicraft

meat, leather

tamanduá (Anteater)

113

handicraft

leather

medicinal

fat 
Bonifácio, K.M. et al.

Table 5. Animal species known and/or used for medicinal purposes by communities surrounding the EPA Chapada do Araripe, Ceará (NE Brazil).

Family/Species/Local name Citations

Use

value

\section{BIRDS}

\section{Tinamidae}

Crypturellus noctivagus zabele

(Spix, 1825) "yellow-legged tinamou"

\section{Cracidae}

Penelope superciliaris Temminck, 1815

"guan"

\section{MAMMALIA}

Dasypodidae

Dasypus novencimctus (Linnaeus, 1758)

"common armadillo"

Euphractus sexcinctus (Linnaeus, 1758)

"six-banded armadillo"

\section{Canidae}

Cerdocyon thous (Linnaeus, 1766)

"fox"

\section{Mustelidae}

Conepatus semistriatus (Boddaert, 1785)

"skunk"

\section{Cervidae}

Mazama gouazoubira (G. Fischer, 1814)

"common deer"

0.0

Salience Used part

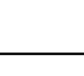

\section{Indications}

\author{
Indications
}

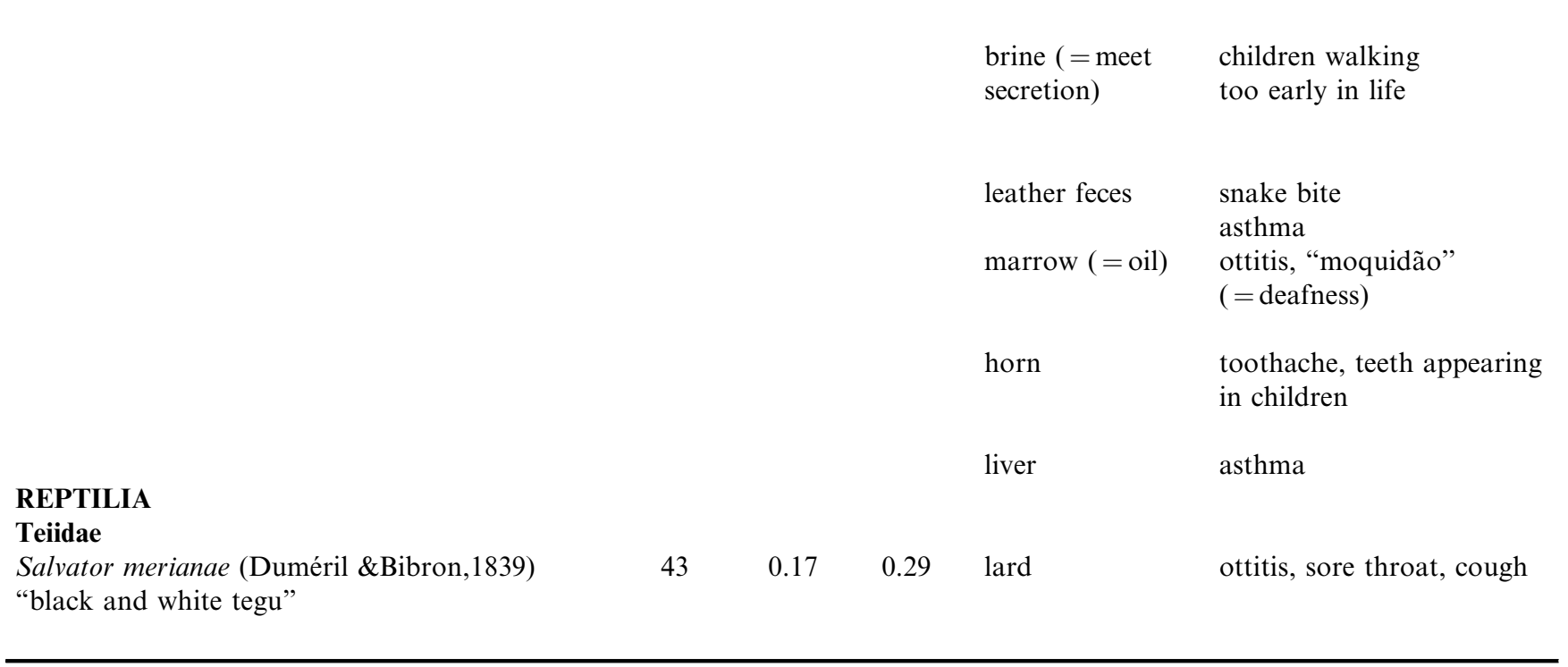

In the studied communities, there was a smaller number of vertebrate species used for medicinal purposes than in other areas of the caatinga biome. Examples of this include the works of Alves et al. (2011) and Alves et al. (2012), which documented the use of 47 and 15 species respectively. As in other ethnozoological works done in different biomes, the number of species with medicinal use in this study was also low. Yirga et al. (2011), for example, reported the use of 66 species in Ethiopia; Benítiz (2011) reported the use of 26 species in Granada Province, Spain; Bagde \& Shampa (2013), in communities adjacent to the Pench National Park in India, documented the medicinal use of 30 species. The few records of medicinal use found in this study may be a reflection of the recovery of species by type of use between men and women, 
since in this study $70.32 \%$ of respondents were men; however, knowledge of men and women regarding medicinal species did not differ greatly $(\mathrm{n}=101$ mentions of use, being 52 mentions by men and 49 by women). Still regarding gender, women tend to know about the use of species that are more closely related to the medical category, while men show a better knowledge of species in the food category; however, this knowledge may vary from region to region, and it may be similar or different (Lucena et al. 2012).

The most mentioned species used as a medicinal resource in the studied communities was the tiú, Salvator merianae (Duméril \& Bibron, 1839): 4 diseases, 43 mentions $(\mathrm{FL}=$ $100 \%$ ), which, together with the common deer, M. gouazoubira (10 diseases, 33 mentions), accounted for $51.85 \%$ of treatment indications (Table 2). Alves et al. (2010) also reported the indication of tiú lard, S. merianae, in the treatment of four different types of diseases. In the Argentine Chaco, the lard of this species was equally important as medicine (Altrichter 2006), which demonstrates the wide geographic distribution of tiú, S. merianae, and its relevance for therapeutic purposes. A pharmacological study by Ferreira et al. (2010) depicts that oil derived from the fat of $S$. merianae has anti-inflammatory action. For the species $M$. gouazoubira, therapeutic indications or purposes recorded in this study were higher when compared to the indications documented in other ethnozoological research as similar to the Mazama gender, a record demonstrating the medicinal potential of this species in the communities studied. Gehara et al. (2009) in their study with residents of Ibitipoca State Park in Minas Gerais, Brazil, found medical reports only of horn scraping, which is indicated for colic. The use of horn scraping was recorded in this study, but with other reported therapeutic indications, such as for toothache and tooth eruption in children. It is noteworthy that the medical efficiency of therapeutic indications of common deer $(M$. gouazoubira) products are yet unproven.

In the communities studied, $62.5 \%$ of different species $(n=5)$ were prescribed to treat more than one disease: the lard of common deer, M. gouazoubira; possum, Conepatus semistriatus (Boddaert, 1785); and foxes, Cerdocyon thous (Linnaeus, 1776) was recommended for rheumatism; common deer shin, $M$. gouazoubira, possum lard, C. semistriatus, tiú lard, S. merianae and common armadillo tail, D. novemcinctus, for otitis. In other studies, these species have records of therapeutic indications (Alves \& Alves 2011, Ferreira et al. 2012, Martínez 2013). However, except for the use of lard of $S$. merianae, there is no pharmacological evidence for the effectiveness of other uses. The pharmacy hypothesis (Begossi 2012), in which species for medicinal use are not the most important for consumption, is not confirmed for the studied communities, probably due to the few existing resources to be exploited in the region. In the case studied, maximizing the use of exploited species should be stressed, since that may be a key-point for the maintenance of local species.

It is worth noting that more than one product of the same species was indicated to treat the same disease, with differences on how to use it. In the Caldas community, possum $(C$. semistriatus) urine, was indicated to treat rheumatism: "... three drops in the joints once a day until getting better, or drink a tablespoon once a day, any time" (N. B., 52 years old); while in the Novo Horizonte community, lard was recommended for this purpose: "one boils the lard, melt it, lays on a glass, let it cool and spread in the joints" (B. A., 45 years old). These results support the concept of utilitarian redundancy (Albuquerque \& Oliveira 2007), which assumes that one disease may be treated by more than one animal species. The medicinal use of animals for the same purpose suggests that different species may share similar medicinal properties (Ahmed \& Ahmed 2011). Ferreira et al. (2013) emphasize that the inclusion of a species in treating more than one disease can trigger a mechanism to reduce the impact on other animals with medicinal purposes.

3.3. Handicraft resource. Regarding handicraft use, five species were mentioned for this purpose (Table 4): common deer, $M$. gouazoubira (45 mentions); agouti, D. prymnolopha (2); anteater, T. tetradactyla (4); and fox, C. thous (1).

The body parts mentioned were leather, horn, tail, feet and nail. Leather was the product most often used for handicraft purposes $(65.38 \%$ mentions for this use), particularly in the manufacture of musical instruments (tambourine, drum and bass drum), household items (chair upholstery, stools), personal utensils (belt, knapsack, doublet, blanket), and making of "reios" (belts) for use in flour mills. VasconcelosNeto et al. (2012), in the Paraiban semiarid, recorded the use of anteater leather, T. tetradactyla, in the production of tambourines and drums.

Out of all the species used for handicraft $(n=5)$, the common deer, M. gouazoubira, stood out as the most used in the four communities, with $86.53 \%$ mentions for the uses mentioned above. Gil \& Guiascón (2012), in Mayan communities, Mexico, reported the use of Mazama sp. leather for upholstery (chair seats), handbags, belts and shoes. Altrichter (2006) also documented the use of $M$. gouazoubira leather by peasants of the Argentine Chaco.

3.4. Symbolic resource. The common deer, M. gouazoubira, was the only species recorded in the symbolic use category in the communities studied with 15 mentions (Table 4), of which $46.66 \%$ occurred in the community of Novo Horizonte, supporting the hypothesis of a more diverse and deeper knowledge of the use of $M$. gouazoubira in this community. According to reports from hunters $(n=8)$, the horn and the paw of the common deer have a great power to bring good fortune; in hunting activities, they're said to draw prey. They often carry these items on themselves as a protection amulet or keep them at home to expel bad mojo. This practice still persists in the minds of these people, a fact confirmed in opportune occasions observing the use of horn keychains for car keys, and paws kept at homes in the Banco de Areia and Farias communities ( $\mathrm{n}=2$ observations at each site), during the study period. Recent acquisitions of these amulets by the lead researcher of this study, in a period between six months and one year, in the communities of Farias and Banco de Areia, denote that this species is still exploited in the region. The use of the common deer paw as an amulet (against bad mojos) was also recorded in other sites in the same state where the study was conducted (Ferreira et al. 2009, Teles et al. 2013), which confirms the spread of this practice in the EPA region of Chapada do Araripe.

\section{Use value and Smith's Salience Index}

The use value (UV) analysis of the 15 species mentioned indicated an UV between 0.03 and 1.34, which shows considerable variation in the use and/or knowledge of the species in studied communities (Table 4). For most species, a low UV $(<0.5)$ was found; only one species had a very high 
UV, greater than 1.0: the common deer, M. gouazoubira (1.34). Four other species showed a UV higher than 0.5: guan, $P$. superciliaris $(\mathrm{UV}=0.86)$; agouti, D. prymnolopha (0.84); common armadillo, D. novemcinctus (0.81); and peba, $E$. sexcinctus (0.80), thus representing species of greatest cultural relevance. By using the UV as a parameter, these species have had their cultural importance investigated in the semiarid region of Paraíba, Brazil (Barbosa et al. 2011) and in Mexico (Gil \& Guiascón 2012).

A comparison of the UV of M. gouazoubira recorded in this study with other ethnozoological studies conducted in Brazil revealed that, in these studies, this species showed a very low UV, as in studies conducted by Souto et al. $(2011,2012)$ in the Caatinga biome, $\mathrm{UV}=0.03$ and 0.04 , respectively; and by Alves \& Rosa (2007), UV $=0.25$ among medicinal animal dealers, also in the same biome. The difference between the use values found in this and in other studies may be explained by the environmental context of the use of the common deer. Local communities, due to daily contact with biological resources, developed a system of knowledge in which a more familiar resource will have greater use versatility; on the other hand, among sellers in public markets, knowledge on the use of biological resources tends to be more general due to the number of species used with different objectives. In addition, knowledge of sellers is restricted to the species most sought after by people.

The general Smith's Index identified that the species with the greatest value of salience $(0.74)$, which is also the one with the highest UV, is the common deer ( $M$. gouazoubira), confirming the cultural importance of this species to the studied local communities.

Pearson's Correlation test showed high correlation between the UV and the Smith's Index (S): $\mathrm{r}=0.87, \mathrm{p}<0.001$. Therefore, the common deer, M. gouazoubira is, a priori, the most culturally important species (according to Cristancho \& Vining 2004, Garibaldi \& Turner 2004), and a priority for conservation. Note that, not all cultural keystone species will have the same characteristics in different cultures. Therefore, to clearly identify a cultural keystone species is necessary to define the indicators based on the cultural system studied (Platten \& Henfrey 2009) and understand it in a systemic perspective.

At the challenge to clearly identify the cultural key species, it is recommended that decision makers have very carefully before including them in conservation strategies (Power et al. 1996). Nuñez \& Simberloff (2005) point out the presence or insertion of invasive species in local communities by using the CKS method. According to the authors, these species can acquire important value to people after his introduction as to replace the key role of native species. In this regard, Sampaio \& Schmidt (2013) points out that biological invasions are recognized as the second leading cause of biodiversity loss on the planet. The occurrence of invasive alien species in protected areas has led to consequences such as alteration of species composition and ecosystem processes and, in extreme cases, the local extinction of species.

Of the animal species mentioned as having use value in the studied communities $(\mathrm{n}=15)$, only the Zabele bird, Crypturellus noctivagus (Wied, 1820), is listed in the National List of Brazilian endangered Fauna Species and is considered "VU" (vulnerable) (Piacentini \& Straube 2008). In IUCN's Official endangered Species list (2014), the species C. noctivagus is evaluatd as "NT" (Near threatened); other recorded species $(93.33 \%)$ are in the category "LC" (Least concern).

\section{CKS from the surrounding communities of EPA Chapada do Araripe}

Five ethnospecies were mentioned as locally preferred: common deer, M. gouazoubira; guan, P. superciliaris; agouti, D. prymnolopha; common armadillo, D. novemcinctus; and peba, E. sexcinctus. The value of the general Identification Index of Cultural Influence (ICI) obtained for the species $M$. gouazoubira $(\mathrm{ICI}=9.68)$ was the highest among the evaluated ethnospecies, indicating that this is a cultural keystone species, and can be considered as a priority for conservation and management (Table 6). Three species obtained ICI between 5.92 and 8.02, indicating that they are relevant for conservation, and only one species, peba, E. sexcinctus, showed a low ICI value (5.0), suggesting that this species is of minor importance to the studied communities, and, therefore, is considered of lower priority regarding conservation of cultural biodiversity. This result confirms the position of Albuquerque \& Medeiros (2013) in stating that, within a cultural system, the choice and the use of a species is a result of the cultural and biological factors in which a local community is inserted.

5.1. Characterization of CKS M. gouazoubira. Worldwide, cervidae play an important role in local communities due to its importance as a hunting resource (Pinder \& Leeuwenberg 1997). The common deer, M. gouazoubira, which occurs in all biomes of Brazil (Duarte et al. 2012), is widely used in the EPA Chapada do Araripe but is not emphasized as an essential component in the diet of local communities, given that other wild species also have a similar role as food. The high value attributed to this species is notable for its history and multitude of uses, because, according to interviewees, in the 1930s, hunting, in association with farming of cassava, was driven by the need to guarantee a protein source for families, exemplified by F. N.'s testimony, a resident of the community of Farias (65 years old): "The mountain was everybody's; food for poverty". This practice of subsistence hunting was intense until the year of 1965, when the National Forest of Araripe ("FLONA Araripe") was created and hunting was forbidden in Brazil by the Forest Code (Federal Law no. 5197/67). However, it happens to the present day, as the uses found in the studied communities show. According to Melo et al. (2014), the social practice of mammalian use still persists in the EPA Chapada do Araripe, probably due to rooted traditions, poverty and lack of stricter inspections.

Another characteristic that has helped to strengthen the high cultural value of the species M. gouazoubira is the intensified connection of residents of the studied communities with wildlife resources, which makes it a remarkable and very popular animal for the local people. All four studied communities have a territorial overlap with the National Forest of Araripe, thus respondents demonstrated having a refined ecological knowledge about this cervidae, including behavioral aspects ("smart animal"), taxonomic ("looks like a goat"), food preferences ("where there's fruit, he eats") and spatial distribution ("you only find it in the deep forest"). Expressions like "has much; is rare to see" suggest that M. gouazoubira is very common in the EPA and in the National Forest. The common deer, M. gouazoubira, is a small deer, with an average height of $50 \mathrm{~cm}$, which is always associated to and dependent on forests for shelter and food, being markedly frugivorous (Pinder \& Leeuwenberg 1997).

As for availability, according to respondents, M. gouazoubira is the most abundant when compared to other species since the creation of the National Forest of Araripe. The presence of this 
Table 6. Average rating of animal species for the evaluation variables of a CKS (adapted from Garibaldi \& Turner 2004). $3=$ very; $2=$ reasonable; $1=$ little; $0=$ none.

\begin{tabular}{|c|c|c|c|c|c|c|}
\hline \multirow{2}{*}{\multicolumn{2}{|c|}{ Variables / CKS evaluation questions }} & \multicolumn{5}{|c|}{ Species / Common name / Average results } \\
\hline & & $\begin{array}{l}\text { M. } \\
\text { gouazoubira } \\
\text { "common } \\
\text { deer" }\end{array}$ & $\begin{array}{c}P . \\
\text { superciliaris } \\
\text { "guan" }\end{array}$ & $\begin{array}{c}\text { D. } \\
\text { prymnolopha } \\
\text { "agouti" }\end{array}$ & $\begin{array}{c}\text { D. } \\
\text { novemcinctus } \\
\text { "common } \\
\text { armadillo" }\end{array}$ & $\begin{array}{l}\text { E. } \\
\text { sexcinctus } \\
\text { "six-banded } \\
\text { armadillo" }\end{array}$ \\
\hline 1 & $\begin{array}{l}\text { Uses } \\
\text { Is the species an important part of the diet and/ } \\
\text { or does it have multiple uses? (A espécie é } \\
\text { importante componente da dieta e/ou tem } \\
\text { múltiplos usos?) }\end{array}$ & 3.16 & 1.98 & 1.97 & 2.0 & 1.0 \\
\hline 2 & $\begin{array}{l}\text { Popularity } \\
\text { Is the species recognized in all its details? (A } \\
\text { espécie é reconhecida em detalhes?) }\end{array}$ & 2.80 & 3.0 & 3.0 & 2.92 & 3.0 \\
\hline 3 & $\begin{array}{l}\text { Availability } \\
\text { Does the species still exist? Is it easily seen? (A } \\
\text { espécie ainda existe? É fácil de ver?) }\end{array}$ & 3.0 & 3.0 & 2.99 & 1.0 & 1.0 \\
\hline 4 & $\begin{array}{l}\text { History } \\
\text { Does the species stand out in popular stories? (A } \\
\text { espécie é destacada em narrativa popular?) } \\
\text { TOTAL = ICI }\end{array}$ & 0.72 & 0.04 & 0.01 & 0 & 0 \\
\hline & TOTAL $=$ ICI & 9.68 & 8.02 & 7.97 & 5.92 & 5.0 \\
\hline
\end{tabular}

deer is recognized by its footprints on trails/roads commonly used by respondents in agricultural activities, extraction and/or displacement from one community to another, a fact confirmed during fieldwork. The availability of the species M. gouazoubira in the study area can be justified by the fact that this species is the most abundant in South America, occupying forest areas and open fields, cerrado and caatinga, and it can be found in agricultural and anthropic areas (Duarte et al. 2012).

Regarding the historical aspects of M. gouazoubira, it proved to be restricted to those attending and/or having attended the National Forest of Araripe during extractive and/or hunting activities. However, due to oral stories, exploits and experienced hunting adventures were fairly shared by all communities. These stories are kept alive in people's memories. There are reports that the capture of this species is regulated by a symbolic universe and tactics as well as teamwork are needed in order to slaughter it. Hunting is a type of recreational activity that depends on a hunter's various skills to succeed, as well as on refined knowledge of the environment and particular circumstances of the target species, as highlighted by Kaltenborn et al. (2013).

The context of the results suggests that the common deer, $M$. gouazoubira, is an important component of the local culture of populations adjacent to the EPA Chapada do Araripe, not as a food source, but as an element embedded in cultural practice. Therefore, insertion of local knowledge is relevant to management decisions and wildlife conservation of the EPA Chapada do Araripe.

\section{Conclusions}

For the communities studied in the vicinity of the EPA Chapada do Araripe, the species with the highest use value, the most mentioned and with the highest salience was the common deer, M. gouazoubira; therefore, this species should be prioritized in conservation actions and studies. This fact was also confirmed by the CKS method, which also indicated the species M. gouazoubira as worthy of conservation attention.
The use of the CKS method to establish priority species for conservation implies the incorporation of local relevant aspects still little explored in the decision-making processes, such as recovering the entire history of the species assessed regarding its cultural and biological aspects from the knowledge of local communities. In addition, the measurement of these attributes may minimize one of the criticisms of the prioritization method traditionally used, as it will provide the reduction of subjectivism in identifying the importance of priority species for conservation, because a quantitative index is used for its determination: ICI. The results of this study are unprecedented regarding the conservation of wild animals and present relevant issues for future work on the management and conservation of M. gouazoubira in the EPA Chapada do Araripe. For example, in the pressure-for-use scenario, it is important to know and understand how local communities are affecting and/or promoting the maintenance of animal populations and how these social actors can participate in conservation strategies.

One of the limitations to wildlife conservation is the lack of knowledge about a species' distribution, biology and ecology. In the case of $M$. gouazoubira, the scarce information about the living conditions of its wild populations puts them in the Least Concern category on the IUCN List, limiting the possibility of working on conservation strategies. According to Duarte et al. (2012), among future actions aimed at the conservation of the species $M$. gouazoubira, studies on population estimates for understanding the dynamics of these populations and the expansion of protected areas in federal, state, and municipal government as a measure for effective and urgent conservation are included. According to the same authors, to date, there is no conservation program directed to this species in Brazil.

\section{Acknowledgements}

KM Bonifácio would like to thank CAPES for the scholarships for doctorates; EMX Freire and A. Schiavetti 
are thankful for the research grants from CNPq (309424/2011-9 and 310799/2009-0, respectively). Special thanks to the informants of the studied communities (Caldas, Farias, Novo Horizonte and Banco de Areia) surrounding the EPA Chapada do Araripe, who were indispensable for the accomplishment of this research.

\section{References}

ALBUQUERQUE, U.P., ARAÚJO, E.L., EL-DEIRA, C.A., LIMA, A.L.A, SOUTO, A, BEZERRA, B.M, FERRAZ, E.M.N, FREIRE, E.M.X, SAMPAIO, E.V.S.B, LAS-CASAS, F.M.G, MOURAS, G.J.B., PEREIRA G.A., MELO, J.G., RAMOS, M. A., RODAL, M.J.N., SCHIEL, N., LYRA-NEVES, R.M., ALVES, R.R.N., AZEVEDO-JÚNIOR, S.M., TELINOJÚNIOR, W.R. \& SEVERI, W. 2012. Caatinga Revisited: ecology and conservation of an important seasonal dry forest. Sci World J1-18, http://dx.doi.org/10.1100/2012/205182

ALBUQUERQUE, U.P. \& MEDEIROS, P.M. 2013. Introdução à etnobiologia de bases ecológicas e evolutivas. In Etnobiologia: Bases Ecológicas e Evolutivas. (U.P Albuquerque, org.). Recife: NUPEEA, p. 9-14.

ALBUQUERQUE, U.P. \& OLIVEIRA, R.F. 2007. Is the use-impact on native Caatinga species in Brazil reduced by the high species richness of medicinal plants?. J Ethnopharmacol 113:156-170, http://dx.doi.org/10.1016/j.jep.2007.05.025

ALTRICHTER, M. 2000. Importancia de los mamiferos silvestres en la dieta de pobladores de la Península de Osca, Costa Rica. Revista Mexicana de Mastozoología 4:95-103.

ALTRICHTER, M. 2006. Wildlife in the life of local people of the semi-arid Argentine Chaco. Biodivers Conserv 15:2719-2736, http://dx.doi.org/10.1007/s10531-005-0307-5

ALVES, R.R.N. 2009. Fauna used in popular medicine in Northeast Brazil. J Ethnobiol and Etnomed 5:1-11, http://dx.doi.org/10.1186/ 1746-4269-5-1

ALVES, R.R.N. 2012. Relationships between fauna and people and the role of ethnozoology in animal conservation. Ethnobio Conserv. 1 (2): 1-69.

ALVES, R.R.N. \& ALVES, H.N. 2011. The faunal drugstore: animal based remedies used in traditional medicines in Latin America. $\mathrm{J}$ Ethnobiol and Etnomed 7(9):1-43, http://dx.doi.org/10.1186/17464269-7-9

ALVES, R.R.N., BARBOSA, J.A.A., SANTOS, S.L.D.X., SOUTO, W.M.S. \& BARBOZA, R.R.D. 2011. Animal-Based Remedies as Complementary Medicines in the Semi-Arid Region of Northeastern Brazil. Evid-Based Compl Alt 1-15, http://dx.doi.org/ 10.1093/ecam/nep134

ALVES, R.R.N. \& DIAS, L.P. 2010. Usos de invertebrados na medicina popular no Brasil e suas implicações para conservação. Trop Conserv Sci 3(2):159-174.

ALVES, R.R.N., GONÇALVES, M.B.R. \& VIEIRA, W.L.S. 2012. Caça, uso e conservação de vertebrados no semiárido brasileiro. Trop Conserv Sci 5(3): 394-416.

ALVES, R.R.N., OLIVEIRA, M.G.G., BARBOZA, M.M.D. \& LOPEZ, L.C.S. 2010. An ethnozoological survey of medicinal animals commercialized in the markets of Campina Grande, NE Brazil. Hum Ecol Rev 17(1):11-17.

ALVES, R.R.N. \& ROSA, I.L. 2007. Zootherapeutic practices among fishing communities in North and Northeast Brazil: a comparison. J Etnopharmacol 111: 82-103, http://dx.doi.org/10.1016/j.jep.2006. 10.033

ALVES, R.R.N. \& SOUTO, W.M.S. 2010. Alguns desafios e dificuldades associadas as pesquisas etnozoológicas no Brasil. In A etnozoologia no Brasil: importância, status atual e perspectiva (R. R.N, Alves, W.M.S., Souto \& Mourão, J.S., orgs). NUPEEA, Recife, p. 59-65.
ARAÚJO, F.S., MARTINS, F.R., SHEPHERD, G.J. 1999. Variações estruturais e florísticas do carrasco no Planalto da Ibiapaba, Estado do Ceará. Rev. Brasil. Biol., 59(4): 663-678, http://dx.doi. org/10.1590/S0034-71081999000400015

ASSIS, A., HANAZAKI, N., REIS, M.S., MATTOS A. \& PERONI N. 2010. Espécie-chave cultural: indicadores e aplicabilidade em Etnoecologia. In Etnoecologia em Perspectiva: natureza, cultura e conservação (A.G.C., Alves, F.J.B, Souto \& Peroni, N., orgs). Recife: NUPEEA. p. 165-186.

BAGDE, N. \& SHAMPA, J. 2013. An ethnozoological studies and medicinal values of vertebrate origin in the adjoining areas of Pench National Park of Chhindwara District of Madhya Pradesh, India. Indian Int. J. of Life Sciences 1(4):278-283.

BARBOSA, J.A.A., NOBREGA, V.A. \& ALVES, R.R.N. 2011. Hunting practices in the semiarid region of Brazil. Indian J Tradit Know 10:486-490.

BARNES, J.I. 2008. Cacao: a cultural keystone species among the Kuna of three communities in San Blas, Panama. Masters dissertation, Carleton University, Canada.

BEGOSSI, A. 1992. Food Taboos at Búzios Island (Brazil): Their Significance and relation to Folk Medicine. J. Ethnobiol. 12 (1):117-139.

BENÍTIZ, G. 2011. Animals used for medicinal and magico-religious purposes in western Granada Province, Andalusia (Spain). J Etnopharmacol 137:1113-1123, http://dx.doi.org/10.1016/j.jep.2011. 07.036

BÉRNILS, R.S. \& COSTA, H.C. 2010. Brazilian reptiles - list of species. http://www.sbherpetologia.org.br/checklist/repteis.htm. (último acesso em 15/01/2012).

BERND, H.R. 1996. Research methodsd in anthrpology: qualitative and quantitative approaches. AM J Eval 17: 91-92, http://dx.doi. org/10.1177/109821409601700112

BORGATTI, S.P. 1996. Anthropac 4.0. Natick: Analytic Technologies.

CADASTRO NACIONAL DE UNIDADES DE CONSERVAÇÃO CNUC. 2011. http://www.mma.gov.br/images/arquivos/areas_protegidas/cnuc/tabela_ucs_bioma_\%2012junho2012.pdf. (ultimo acesso em 22/07/2012).

CADASTRO NACIONAL DE UNIDADES DE CONSERVAÇÃO CNUC. 2015. http://www.mma.gov.br/images/arquivo/80112/ CNUC_Bioma_Fevereiro_2015.pdf (ultimo acesso em 22/05/2015).

COLDING, J. \& FOLKE, C. 2001. Social taboo: invisible system of local resource management and biological conservation. Ecol. Appl. 11(2):584-600, http://dx.doi.org/10.1890/1051-0761(2001)011 [0584:STISOL]2.0.CO;2

COLWELL, R.K. 2009.EstimateS: Statistical estimation of species richness and shared species from samples. Version 8.2. http://viceroy.eeb.uconn.edu/EstimateS. (último acesso em 15.08.2012).

COLWELL, R.K. \& CODDINGTON, J.A. 1994. Estimating terrestrial biodiversity through extrapolation. Phi Trans R Soc Lond B 345:101-118, http://dx.doi.org/10.1098/rstb.1994.0091

COMITÊ BRASILEIRO DE REGISTROS ORNITOLÓGICOS CBRO. 2011. Lista das aves do Brasil. http://www.cbro.org.br/ CBRO/index.htm. (último acesso 15/01/2012).

COSTA-NETO, E.M. 2000. Conhecimento e usos tradicionais de recursos faunísticos por uma comunidade afro-brasileira. Resultados preliminaries. Interciencia 25(9):423-431.

CRISTANCHO, S. \& VINING, J. 2004. Culturally defined keystone species. Hum Ecol Rev 11(2):153-164.

DONNELL, K.P., PAJARO, M.G. \& VINCENT, A.C.J. 2010. How does accuracy of fisher knowledge affect seahorse conservation status?. Anim Conserv 1-8, http://dx.doi.org/10.1111/j.1469-1795.2010.00377.x

DUARTE, J.M.B., VOGLIOTTI, A., ZANETTI, E.S., OLIVEIRA, M.L., TIEPOLO, L.M., RODRIGUES, L.F. \& ALMEIDA, L.B. 2012. Avaliação do risco de extinção do veado-catingueiro Mazama gouazoubira G. Fisher [von Waldheim], 1814, no Brasil. Biodiversidade Brasileira 3:50-58.

FERREIRA, F.S., ALBUQUERQUE, U.P., COUTINHO, H.D.M., ALMEIDA, W.O. \& ALVES, R.R.N. 2012. The Trade in 
Medicinal Animals in Northeastern Brazil. Evid-Based Compl Alt 1-20, http://dx.doi.org/10.1155/2012/126938

FERREIRA, F.S., BRITO, S.V., RIBEIRO, S.C., SARAIVA, A.A.F., ALMEIDA, W.O. \& ALVES, R.R.N. 2009. Animal-based folk remedies sold in public markets in Crato and Juazeiro do Norte, Ceará, Brazil. BMC Complem Altern M 9:1-8, http://dx.doi.org/ 10.1186/1472-6882-9-17

FERREIRA, F.S., BRITO, S.V., SARAIVA, R.A., ARARUNA, M.K.A., MENEZES, I.R.A., COSTA, J.G.M., COUTINHO, H.D.M., ALMEIDA, W.O. \& ALVES, R.R.N. 2010. Topical anti-inflammatory activity of body fat from the lizard Tupinambis merianae. J Ethnopharmacol 130:514-520, http://dx.doi.org/10.1016/j.jep.2010.05.041

FERREIRA, F.S., FERNANDES-FERREIRA, H.F., LÉO NETO, N.A, BRITO, S.V. \& ALVES, R.R.N., 2013. The trade of medicinal animals in Brazil: status and perspectives. Biodivers Conserv 22:839-870, http://dx.doi.org/10.1007/s10531-013-0475-7

FRIEDMAN, J., YANIV, Z., DAFNI, A. \& PALEWITCH, D. 1986. A preliminary classification of the healing potential of medicinal plants, based on a rational analysis of an ethnophannacologlcal field survey among Bedouins in the Negev Desert, Israel. J Ethnopharmacol 16:275-287, http://dx.doi.org/10.1016/0378-8741(86) 90094-2

GARIBALDI, A. \& TURNER, N. 2004. Cultural keystone species: implication for ecological conservation and restoration. Ecol Soc 9. http://www.ecologyandsociety.org/vol9/iss3/art1. (útimo acesso em 03/03/2012)

GARIBALDI, A. 2009. Moving from model to application: cultural keystone species and reclamation in Fort McKay, Alberta. J Ethnobiol. 29(2):323-338, http://dx.doi.org/10.2993/0278-0771-29.2.323

GEHARA, M.C.M., RIBEIRO, G.C., BISAGGIO, E.L. \& ANDRIOLO, A. 2009. Conhecimento popular de moradores do Parque Estadual do Ibitipoca (MG, Brasil) sobre o gênero Mazama Rafinesque, 1817 (Cervidae). Sitientibus 9(2/3): 122-128.

GIL, R.A.P. \& GUIASCÓN, O.G.R. 2012. Uso de la fauna Silvestre en la comunidade maya de Villa Guadalupe, Capeche, México. Etnobiología 10(2):1-11.

HUNT, L.M. 2013. Using human-dimensions research to reduce implementation uncertainty for wildlife management: a case of moose (Alces alces) hunting in northern Ontario, Canada. Wildlife Res 40: 61-69, http://dx.doi.org/10.1071/WR12185

HURTADO-GONZALES, J.L. \& BODMER, R.E. 2004. Assessing the sustainability of brocket deer hunting in the TamshiyacuTahuayo Communal Reserve, northeastern Peru. Biol Conserv 116:1-7, http://dx.doi.org/10.1016/S0006-3207(03)00167-8

INSTITUTO BRASILEIRO DO MEIO AMBIENTE E DOS RECURSOS NATURAIS - IBAMA. 2004. Plano de Manejo da Floresta Nacional do Araripe. Brasília.

JORGENSON, J.P. 1995. Maya subsistence hunters in Quintana Roo, Mexico. Oryx 29, 49-57, http://dx.doi.org/10.1017/S0030605300020871

KALTENBORN, B.P., ANDERSEN, O. \& LINELL, J.D.C. 2013. Is hunting large carnivores different from hunting ungulates? Some judgments made by Norwegian hunters. J Nat Conserva 21:326333, http://dx.doi.org/10.1016/j.jnc.2013.05.004

LOH, J. \& HARMON, D. 2005. A global index of biocultural diversity. Ecol Indic 5: 231-241, http://dx.doi.org/10.1016/j.ecolind.2005.02.005

LOHANI, U. 2010. Man-animal relationships in Central Nepal. J Ethnobiol Ethnomed 6(31):1-11, http://dx.doi.org/10.1186/1746-4269-6-31

LOPES, P.F.M., FRANCISCO, A.M. \& BEGOSSI, A. 2009. Artisanal commercial fisheries at the southern coast of São Paulo State, Brazil: ecological, social and economic structures. Interciencia 34:8-629.

LUCENA, C.M., COSTA, G.G CARVALHO, T.K.N, GUERRA, N. M, QUIRINO, Z.G.M. \& LUCENA, R.F.P. 2012. Uso e conhecimento de cactáceas no município de São Mamede (Paraíba, Nordeste do Brasil). BioFar 121-134.

MAGURRAN, A.E. 2011. Medindo a diversidade biológica. Curitiba: Editora da UFPR.
MARTÍNEZ, G.J. 2013. Use of fauna in the traditional medicine of native Toba (qom) from the Argentine Gran Chaco region: an ethnozoological and conservacionist approach. Ethnobiology and conservation 2:1-43

MEDEIROS, P.M., LADIO, A.H. \& ALBUQUERQUE, U.P. 2013. Critérios locais de seleção e uso diferencial de plantas medicinais; porque nós escolhemos o que escolhemos?. In Etnobiologia: Bases Ecológicas e Evolutivas (U.P Albuquerque, eds.). Recife: NUPEEA, p 147-165.

MELO, R.S., SILVA, O.C., SOUTO, A., ALVES, R.R.N. \& SCHIEL, N. 2014. The role of mammals in local communities living in conservation areas in the Northeast of Brazil: an ethnozoological approach. Trop Conserv Sci 7(3): 423-439.

MINISTÉRIO DO MEIO AMBIENTE - MMA. Áreas Prioritárias para a Conservação, Uso Sustentável e Repartição de Benefícios da Biodiversidade Brasileira: Atualização - Portaria MMA n 9, de 23 de Janeiro de 2007. Brasília: MMA.

NUÑEZ, M.A. \& SIMBERLOGG, D. 2005. Invasive species and the cultural keystone species concept. Ecol. Soc. 10.

OLIVEIRA, E.S., TORRES, D.F., ALVES, R.R.N. \& VASCONCELLOS, A. 2010. Etnozoologia em áreas protegidas: uso da fauna por populações locais na APA Bonfim / Guaraíras, Rio Grande do Norte, Brasil. In A etnozoologia no Brasil: importância, status atual e perspectiva (R.R.N., Alves, W.M.S., Souto \& J.S., Mourão, eds.). Recife: NUPEEA, p 405-421.

OLIVEIRA, R.L.C., LINS NETO, E.M \& ALBUQUERUQE, U.P. 2007. Conservation priorities and population structure of woody medicinal plants in an area of caatinga vegetation (Pernambuco State, NE Brazil). Environ Monit Assess. 132(1-3): 189-206, http:// dx.doi.org/10.1007/s10661-006-9528-7

PAGLIA, A.P., FONSECA, G.A.B., RYLANDS, A.B., HERRMANN, G., AGUIAR, L.M.S., CHIARELlO, A.G., LEITE, Y.L.R., COSTA, L.P., SICILIANO, S., Kierulff, M.C.M., MENDES S.L., TAVARES, V.C., MITTERMEIER, R.A. \& PATTON, J.L. 2012. Lista anotada dos mamíferos do Brasil, 2. Arlington: Conservation International.

PAINE, R.T.1969. A note of tropic complexity and community stability. Am Nat 103(929):91-93, http://dx.doi.org/10.1086/282586

PEREIRA, J.P.R. \& SCHIAVETTI, A. 2010. Conhecimentos e usos da fauna cinegética pelos caçadores indígenas "Tupinambá de Olivença" (Bahia). Biota Neotrop.10(1):175-183, http://dx.doi.org/ 10.1590/S1676-06032010000100018

PERNAMBUCO. 2007. Secretaria de Ciência, tecnologia e Meio Ambiente - SECTMA. Região do Araripe: diagnóstico florestal. Brasília: MMA.

PFEIFFER, J.M., BUTZ \& BUTZ, R.J. 2005. Assessing cultural and ecologicl variation in ethnobiological research: teh importance of gender. J Ethnobiol 25(2): 240-278, http://dx.doi.org/10.2993/02780771(2005)25[240:ACAEVI]2.0.CO;2

PIACENTINI, V.Q. \& STRAUBE, F.C. 2008. Crypturellus noctivagus noctivagus (Wied, 1829). In Livro Vermelho da Fauna Brasileira Ameaçada de extinção (A.B.M Machado, G.M., Drummond \& A. P., Paglia, eds). Brasília: MMA, p 384-385.

PINDER, L. \& LEEUWENBERG, F. 1997. Veado-catingueiro (Mazama gouazoubira, Fisher 1814). In Biologia e conservação de cervídeos sul-americanos: Blastocerus, Ozotoceros e Mazama (J.M. B, Duarte ed.). São Paulo: FUNEP, p 60-68.

PLATTEN, S. \& HENFREY, T. 2009. The cultural keystone concept: insights form ecological anthropology. Hum Ecol, 37: 491-500, http://dx.doi.org/10.1007/s10745-009-9237-2

POWER, M.E., TILMAN, D., ESTES, J.A., MENGE, B.A., BOND, W.J., SCOTT-MILLS, L., DAILY, G., CASTILLA, J.C., LUBCHENCO, J. \& PAINE, R T. 1996. Challenges in the quest for keystones. BioScience 46: 609-620, http://dx.doi.org/10.2307/1312990

QUIJANO-HERNÁNDEZ, E. \& CALMÉ, S. 2002. Patrones de cacería y conservación de la fauna silvestre en una comunidad maya de quintana roo, México. Etnobiología 2:1-18. 
RIBEIRO-SILVA, S. 2012 Angiosperms from the Araripe National Forest, Ceará, Brazil. Check List 8(4):744-751.

RODRIGUES, R.F. \& ARAÚJO, G.M. 2013. Estrutura da vegetação e características edáficas de um cerradão em solo distrófico e em solo mesotrófico no Triângulo Mineiro. Biosci. J 29(6): 2013-2029.

ROSSATO, S.C., LEITÃO-FILHO, H.F. \& BEGOSSI, A. 1999. Ethnobotany of Caiçaras of the Atlantic Forest Coast (Brazil). Econ Bot 53(4):387-395, http://dx.doi.org/10.1007/BF02866716

SANTOS-FITA, D., NARANJO, E.J. \& RANGE-SALAZAR. 2012. Wildlife uses and hunting patterns in rural communities of the Yucatan Peninsula, Mexico. J Ethnobiol Ethnomed 8(38):1-17, http://dx.doi.org/10.1186/1746-4269-8-38

SMITH, J.J. 1993. Using Anthropac 3.5 and a spreadsheet to compute a freelist salience index. Cultural Anthropology Methodology Newsletter 5:1-3, http://dx.doi.org/10.1177/1525822X9300500301

SOUTO, W.M.S, BARBOZA, R.R.D, MOURÃO, J.S. \& ALVES, R. R.N. 2012. Traditional knowledge of sertanejos about zootherapeutic practices used in ethnoveterinary medicine of NE Brazil. Indian J Tradit Know 11:259-265.

SOUTO, W.M.S, MOURÃO, J.S., BARBOZA, R.R.D. \& ALVES, R.R.N. 2011. Paralleles between zootherapeutic practices in ethnoveterinary and human complementary medicine in northeastern Brazil. J Ethnopharmacol 134: 623-629, http://dx.doi.org/10.1016/j.jep.2011.01.041

SOUSA JÚNIOR, J.R, ALBUQUERQUE, U.P. \& PERONI, N. 2013. Traditional knowledge and management of Caryocar coriaceum Wittm. (Pequi) in the Brazilian Savanna, Northea Stern Brazil. Econ Bot 67(3): 225-233, http://dx.doi.org/10.1007/s12231-013-9241-8
SOUZA, J.B. \& ALVES, R.R.N. 2014. Hunting and wildlife use in an Atlantic Forest remnant of northeastern Brazil. Trop Conserv Sci 7(1):145-160.

TELES, D.A., RODRIGUES, J.K. \& TELES, E.A., 2013. Uso místico e religioso da fauna comercializada em feiras nos municípios de Crato e Juazeiro do Norte, Ceará, Nordeste do Brasil. Etnobiología 11(3):28-33.

TORRES, D.F., OLIVEIRA, E.S., ALVES, R.R.N. \& VASCONCELLOS A. 2009. Etnobotânica e etnozoologia em unidades de conservação: uso da biodiversidade na APA de Genipabu, Rio Grande do Norte, Brasil. Interciencia 34:623-629.

TORRES-AVILEZ, W., NASCIMENTO, A.L.B., CAMPOS, L.Z.O., SILVA, F.S. \& ALBUQUERQUE, U.P. 2014. Gênero e idade. In Introdução à etnobiologia (U.P Albuquerque, org). Recife: NUPEEA, p. 163-167.

UNIÃO INTERNACIONAL PARA A CONSERVAÇÃO DA NATUREZA E DOS RECURSOS NATURAIS - IUCN. 2014. Red List of Threatened Species. Version 2014.1. www.iucnredlist. org (ultimo acesso em 10/06/2014).

VASCONCELOS-NETO, C.F.A.V., SANTOS, S.S., SOUSA, R.F., FERNANDES-FERREIRA, H. \& LUCENA, R.F.P. 2012. A caça com cães (Canis lupus familiaris) em uma região do semiárido do nordeste do Brasi. Biofar, 1-16.

YIRGA, G., TEFERI, M. \& GERBRESLASSEA, Y. 2011. Ethnozoological study of traditional medicinal animals used by the people of Kafta-Humera District, Nothern Ethiopia. Int J Med Sci 3(10): $316-320$. 